\title{
Urban water management: Can UN SDG 6 be met within the Planetary Boundaries?
}

Sørup, Hjalte Jomo Danielsen; Brudler, Sarah; Godskesen, Berit; Dong, Yan; Lerer, Sara Maria; Rygaard, Martin; Arnbjerg-Nielsen, Karsten

\section{Published in:}

Environmental Science and Policy

Link to article, DOI:

10.1016/j.envsci.2020.01.015

Publication date:

2020

Document Version

Peer reviewed version

Link back to DTU Orbit

Citation (APA):

Sørup, H. J. D., Brudler, S., Godskesen, B., Dong, Y., Lerer, S. M., Rygaard, M., \& Arnbjerg-Nielsen, K. (2020). Urban water management: Can UN SDG 6 be met within the Planetary Boundaries? Environmental Science and Policy, 106, 36-39. https://doi.org/10.1016/j.envsci.2020.01.015

\section{General rights}

Copyright and moral rights for the publications made accessible in the public portal are retained by the authors and/or other copyright owners and it is a condition of accessing publications that users recognise and abide by the legal requirements associated with these rights.

- Users may download and print one copy of any publication from the public portal for the purpose of private study or research.

- You may not further distribute the material or use it for any profit-making activity or commercial gain

- You may freely distribute the URL identifying the publication in the public portal 


\section{Urban water management: Can UN SDG 6 be 2 met within the Planetary Boundaries?}

3 Hjalte JD Sørup ${ }^{1,}$, , Sarah Brudler ${ }^{1,2}$, Berit Godskesen ${ }^{1}$, Yan Dong ${ }^{3}$, Sara M Lerer ${ }^{1}$, Martin Rygaard ${ }^{1}$, Karsten

$4 \quad$ Arnbjerg-Nielsen ${ }^{1}$

51 Technical University of Denmark, Department of Environmental Engineering

$6 \quad 2$ VCS Denmark

73 Technical University of Denmark, Department of Management Engineering

$8 \quad *$ Corresponding author: hjds@env.dtu.dk

\section{Abstract}

Water is key to keeping urban areas safe and healthy for humans and hence safe sanitation and waste water treatment is promoted by the United Nations Sustainable Development Goals. We show that emissions from existing state-of-the-art water technologies are problematic from a Planetary Boundaries (PBs) perspective. The magnitude of the climate change impact in relation to the PB based normalization is much higher than for any other PB. The current paradigm for urban water management needs a radical change for society to be served while emissions are reduced to a level that complies with the Planetary Boundaries.

\section{Keywords}

Life Cycle Assessment; Planetary Boundaries; Sustainable Water Management; United Nations Sustainable Development Goals; Urban Water Management 
21 Water is used to establish barriers between humans and potential threats (hygienic and other) which has

22 been of major importance for the historic development of human society and human health (Ferriman,

23 2007). As such, urban water management is essential for urbanization as set forth in the United Nations

24 Sustainable Development Goal (UN SDG) 6 on Water and sustainable management of water is key for creating sustainable communities (UN SDG 11 on cities) (United Nations, 2015). Urban water management incorporates withdrawal of water for consumption purposes (Godskesen et al., 2013; Lundie et al., 2004), handling of wastewater to maintain barriers between humans and hazards (Brudler et al., 2019; Corominas et al., 2013; Delre et al., 2019; Fang et al., 2016; Wenzel et al., 2008), and stormwater management to dampen climatic fluctuations from droughts to flooding (Brudler et al., 2016; Green, 2010). inevitable to fulfil human needs (Ferriman, 2007). It is also increasingly recognized that water systems must be sustainable with respect to all three pillars of sustainability, i.e. to provide these services with due consideration to economy, society and the environment (Belmeziti et al., 2015; Larsen et al., 2016). Hence the question in the title: can we live up to UN SDG 6 and spread modern urban water management to all people in the world without compromising environmental sustainability? 


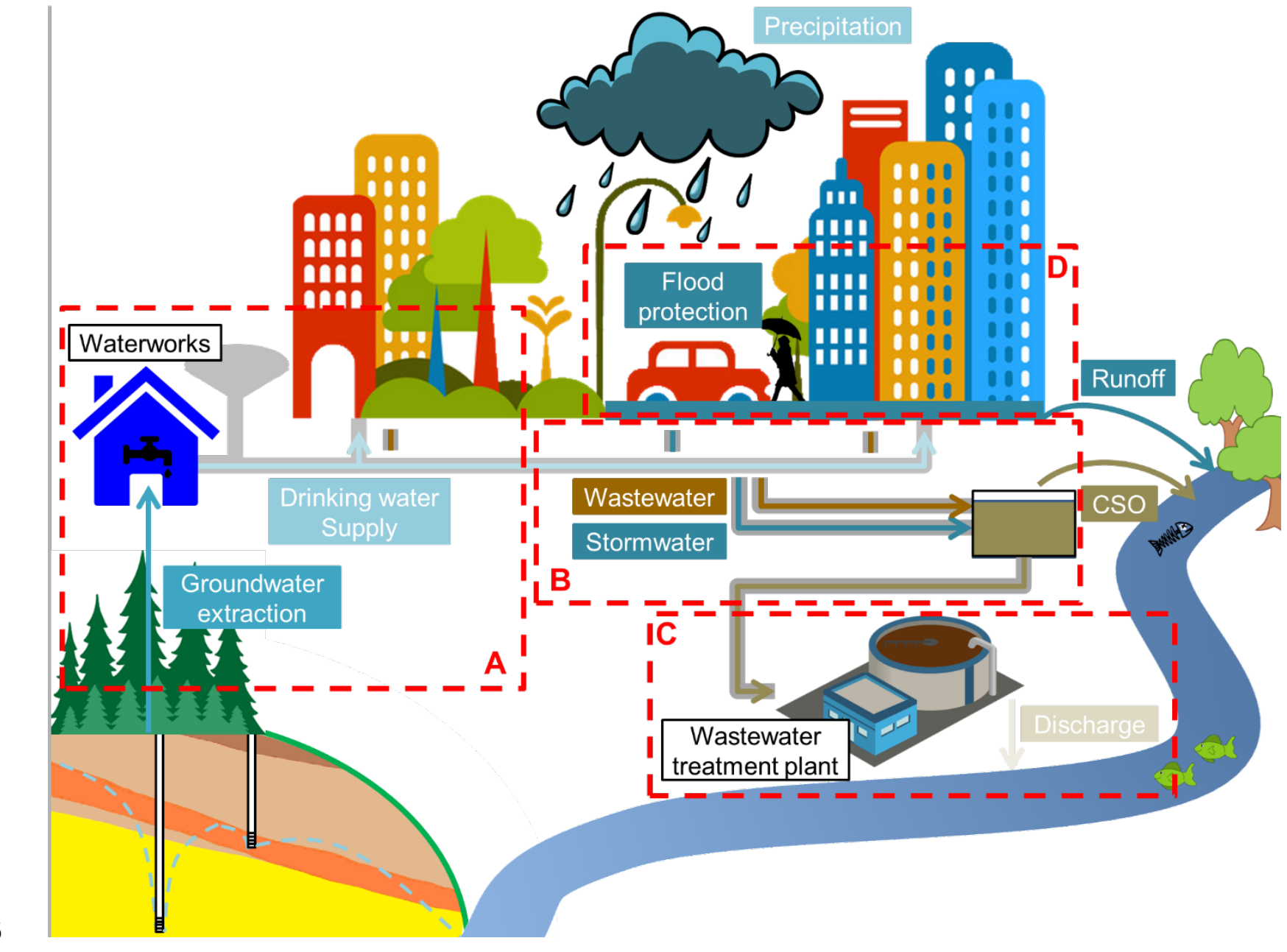

Figure 1 The urban water cycle as presented in Denmark with: A) groundwater based water supply, B) wastewater and stormwater collection systems, C) wastewater treatment including nutrient removal, and D) protection against pluvial flooding. CSO is short for Combined Sewer Overflow.

Life Cycle Assessment (LCA) is a widely accepted and internationally standardized tool to assess

environmental sustainability and has been applied within all areas of urban water management to compare management approaches and technological options (Brudler et al., 2019, 2016; Corominas et al., 2013;

Delre et al., 2019; Fang et al., 2016; Foley et al., 2010; Wenzel et al., 2008). However, marginal

44 improvements may not be sufficient to ensure overall environmental sustainability (Bjørn and Hauschild, 2015; Ryberg et al., 2016). Hence, there is a need to map the best available practices against the definitions of the Planetary Boundaries (PB) where the goal is to keep the Earth System within the stable environmental state of the Holocene (Rockström et al., 2009; Steffen et al., 2015). If PBs should not be 
exceeded, it is necessary to downscale to a more local level to guide strategies and define thresholds(Bjørn and Hauschild, 2015).

\section{Methods}

Data from four existing LCA studies are used in this study

- Water supply: Copenhagen, Denmark: 535000 people receiving service (Godskesen et al., 2013)

- Wastewater treatment: Copenhagen, Denmark: 520000 people receiving service (Delre et al., 2019)

- Stormwater managemet: Odense, Denmark: 14000 people receiving service (Brudler et al., 2019)

- Climate change adaptation: Copenhagen, Denmark: 79000 people receiving service (Brudler et al., 2016)

The different studies, even though most of them from Copenhagen, Denmark, do not cover the exact same spatial areas and thus serve different numbers of people. The system boundaries of the original studies are investigated and adjusted to avoid double counting of any processes, see [Supplementary material].

Each study is re-referenced to a common functional unit relating to the provision of essential societal water services for one person. The impacts arising from each of the service functions is allocated per person according to the number of people benefiting from the service function. That way, the impacts can be compared across studies. In the [Supplementary material] all PBs are investigated, showing that climate change emissions is by far the category with the highest PB exceedance and at the same time the category with the best data coverage. Hence, this is the category focused on in this study. The total allowable GHGs emissions for the number of people receiving the services is calculated using the very strict PB based normalization value of $522 \mathrm{~kg}$ CO2-eq per person per year provided by (Bjørn and Hauschild, 2015). This corresponds to an allowed global warming of $1 \mathrm{~W} / \mathrm{m}^{2}$ and is thus more strict than e.g. the Paris agreement, but still very relevant given the current lack of reductions in actual emissions, and consequential future needs for faster reductions (UNEP, 2019). Finally, the emissions per person from the different services are related to the total allowable emissions of a person as the share a given service is occupying. 


\section{Results and discussion}

While existing LCAs of urban water systems have identified environmentally preferable options, we show that the total emissions of the assessed systems are unacceptable from a PB perspective. Using PB based normalization (Bjørn and Hauschild, 2015) on LCA studies of urban water management in Denmark, we show that even the most favourable solutions will generate greenhouse gas (GHG) emissions that constitute a large fraction of peoples total allowable emissions (Figure 2). This has not been reported by the original studies that focus on comparisons between subsystems of urban water management (Brudler et al., 2019, 2016; Delre et al., 2019; Godskesen et al., 2013). The challenge is even larger than shown here for the thousands of cities globally that deal with more polluted water resources, more extensive treatment and less efficient infrastructure than Denmark (Wang et al., 2019; WWAP, 2017).

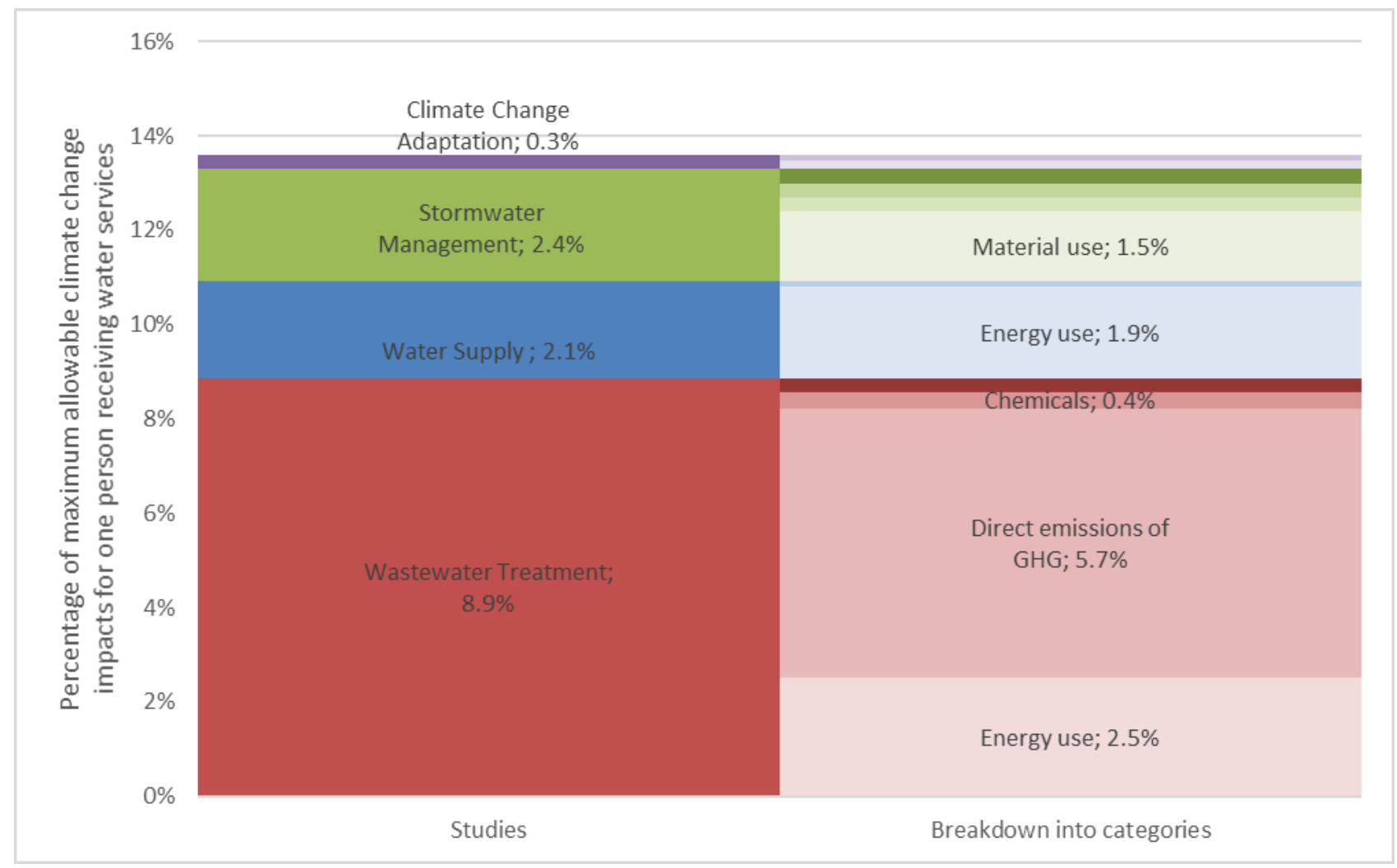

Figure 2 Percentage of maximum allowable climate change impact for one person based on Planetary Boundary normalization of emissions from urban water services in Denmark. 
Climate change related environmental emissions are identified as a very important impact in all the originally assessed studies and this is further backed by the PB based normalization, see [supplementary material]. Climate change impacts are caused by GHG emissions, which mainly arise from direct emissions of methane and nitrous oxide from the wastewater treatment plants; energy use for pumps and aeration in water supply and wastewater treatment systems; and material use, transport, and construction in the stormwater management and associated changes for climate adaptation.

The PB normalization indicates that impacts from urban water management exceed allowable thresholds. While GHG emissions from water services account for close to $14 \%$ of allowable emissions (Fig. 2 ) it is reported to contribute just $1 \%$ of total GHG emissions in Denmark (Nielsen et al., 2017). Exactly how many emissions urban water management can be allowed to generate in a PB sustainable society is in the end a political choice; but the $1 \%$ of all emissions from Nielsen et al., (2017) sets a realistic likely level. It is clear that no gradual improvement of the existing paradigm with concrete and pipes will lead to an acceptable emission level. We showcase how a single decision domain should be broken down to enable a thorough analysis of where to put focus to increase sustainability. Even in a scenario where future electricity production is entirely based on renewables, emissions from electricity use will not be reduced to zero (EEA, 2014; Godskesen et al., 2013), and reductions in emissions from material use and transport will be very uncertain. The direct emission of methane and nitrous oxide from wastewater treatment will not be directly affected, and emission reductions will for this part depend entirely on implementation of new technical solutions not fully developed yet. For water management the solution could be to find alternatives to using water as the primary carrier of pollutants in urban areas or to systematically recover resources and energy in every urban water cycle across the globe (Belmeziti et al., 2015; Larsen et al., 2016).

This is not just another call for reducing GHG emissions but a call to align objectives for and among the SDGs and the Planetary Boundaries recognizing that all three pillars of sustainability are not equally 
important and mutually tradable; A sustainable economy can only flourish within a sustainable society, and a sustainable society can only exist at a healthy sustainable managed planet, governed in respect of the PB.

Challenges remain with linking the PB to LCA and using them on non-global systems (Ryberg et al., 2016; Steffen et al., 2015); these need to be addressed (Randers et al., 2018). Nevertheless, for GHG emissions the PB based normalization appears to be a strong framework to support not only relative environmental impact of solutions to a problem, but also to indicate where fundamentally new local solutions are needed to enable tackling of global problems. It has been demonstrated that peoples' habits need to change to meet the PBs (Springmann et al., 2018), but people cannot directly influence their impact from public services, like urban water management, so it is a societal challenge to deliver these while respecting the PB.

\section{Conclusions}

To answer the question raised in the heading: To meet UN SDG 6 while respecting the PBs, requires first and foremost a dramatic reduction in GHG emissions from urban water management. It requires a total decoupling of GHG emissions and energy and material use, as well as active carbon fixation and/or a reduction of direct GHG emission from the systems, without these changes challenging other PBs not seen as problematic today [supplementary material]. Importantly, changes need to happen at a rate unprecedented for water infrastructure. LCA and PB based assessments are key methodologies for highlighting 1) how far we are from being sustainable and 2) which subsystems require radical new developments before urban water management will be sustainable.

\section{Acknowledgements}

Figure 1 Illustration adapted from unpublished work by Cecilie Thrysøe, Technical University of Denmark, Department of Environmental Engineering. 
to sustainable urban water management systems: how to define expected service functions? Civ. Eng. Environ. Syst. 1-19. https://doi.org/10.1080/10286608.2015.1047355

Bjørn, A., Hauschild, M.Z., 2015. Introducing carrying capacity-based normalisation in LCA: framework and development of references at midpoint level. Int. J. Life Cycle Assess. 20, 1005-1018. https://doi.org/10.1007/s11367-015-0899-2

Brudler, S., Arnbjerg-Nielsen, K., Hauschild, M.Z., Ammitsøe, C., Hénonin, J., Rygaard, M., 2019. Life cycle assessment of point source emissions and infrastructure impacts of four types of urban stormwater systems. Water Res. 156, 383-394. https://doi.org/10.1016/j.watres.2019.03.044

Brudler, S., Arnbjerg-Nielsen, K., Hauschild, M.Z., Rygaard, M., 2016. Life cycle assessment of stormwater management in the context of climate change adaptation. Water Res. 106, 394-404. https://doi.org/10.1016/j.watres.2016.10.024

Corominas, L., Foley, J., Guest, J.S., Hospido, A., Larsen, H.F., Morera, S., Shaw, A., 2013. Life cycle assessment applied to wastewater treatment: State of the art. Water Res. 47, 5480-5492. https://doi.org/10.1016/j.watres.2013.06.049

Delre, A., Hoeve, M., Scheutz, C., 2019. Site-specific carbon footprints of Scandinavian wastewater treatment plants, using the life cycle assessment approach. J. Clean. Prod. 211, 1001-1014. https://doi.org/10.1016/j.jclepro.2018.11.200

EEA, 2014. Trends and projections in Europe 2014, EEA Report 6/2014. https://doi.org/10.2800/93693

Fang, L.L., Valverde-Pérez, B., Damgaard, A., Plósz, B.G., Rygaard, M., 2016. Life cycle assessment as development and decision support tool for wastewater resource recovery technology. Water Res. 88, 538-549. https://doi.org/10.1016/j.watres.2015.10.016

Ferriman, A., 2007. BMJ readers choose the "sanitary revolution" as greatest medical advance since 1840. 
Foley, J., de Haas, D., Hartley, K., Lant, P., 2010. Comprehensive life cycle inventories of alternative wastewater treatment systems. Water Res. 44, 1654-1666. https://doi.org/10.1016/j.watres.2009.11.031

Godskesen, B., Hauschild, M., Rygaard, M., Zambrano, K., Albrechtsen, H.J., 2013. Life-cycle and freshwater withdrawal impact assessment of water supply technologies. Water Res. 47, 2363-2374. https://doi.org/10.1016/j.watres.2013.02.005

Green, C., 2010. Towards Sustainable Flood Risk Management. Int. J. Disaster Risk Sci. 1. https://doi.org/10.3974/j.issn.2095-0055.2010.01.006

Larsen, T.A., Hoffmann, S., Luthi, C., Truffer, B., Maurer, M., 2016. Emerging solutions to the water challenges of an urbanizing world. Science (80-. ). 352, 928-933. https://doi.org/10.1126/science.aad8641

Lundie, S., Peters, G.M., Beavis, P.C., 2004. Life Cycle Assessment for Sustainable Metropolitan Water Systems Planning. Environ. Sci. Technol. 38, 3465-3473. https://doi.org/10.1021/es034206m

Nielsen, O.-K., Plejdrup, M.S., Winther, M., Nielsen, M., Gyldenkærne, S., Mikkelsen, M.H., Albrektsen, R., Thomsen, M., Hjelgaard, K., Fauser, P., Bruun, H.G., Johannsen, V.K., Nord-Larsen, T., Vesterdal, L., Callesen, I., Caspersen, O.H., Rasmussen, E., Petersen, S.B., Baunbæk, L., Hansen, M.., 2017. Denmark's National Inventory Report 2017. Emission Inventories 1990-2015 - Submitted under the United Nations Framework Convention on Climate Change and the Kyoto Protocol. Aarhus University, DCE - Danish Centre for Environment and Energy.

Randers, J., Rockström, J., Stoknes, P.E., Golüke, U., Collste, D., Cornell, S., 2018. Transformation is feasible How to achieve the SustainableDevelopment Goals within Planetary Boundaries. 
Rockström, J., Steffen, W., Noone, K., Persson, Å., Chapin, F.S., Lambin, E.F., Lenton, T.M., Scheffer, M., Folke, C., Schellnhuber, H.J., Nykvist, B., De Wit, C.A., Hughes, T., Van Der Leeuw, S., Rodhe, H., Sörlin, S., Snyder, P.K., Costanza, R., Svedin, U., Falkenmark, M., Karlberg, L., Corell, R.W., Fabry, V.J., Hansen, J., Walker, B., Liverman, D., Richardson, K., Crutzen, P., Foley, J.A., 2009. A safe operating space for humanity. Nature. https://doi.org/10.1038/461472a

Ryberg, M.W., Owsianiak, M., Richardson, K., Hauschild, M.Z., 2016. Challenges in implementing a Planetary Boundaries based Life-Cycle Impact Assessment methodology. J. Clean. Prod. 139, 450-459. https://doi.org/10.1016/j.jclepro.2016.08.074

Springmann, M., Clark, M., Mason-D’Croz, D., Wiebe, K., Bodirsky, B.L., Lassaletta, L., De Vries, W., Vermeulen, S.J., Herrero, M., Carlson, K.M., Jonell, M., Troell, M., DeClerck, F., Gordon, L.J., Zurayk, R., Scarborough, P., Rayner, M., Loken, B., Fanzo, J., Godfray, H.C.J., Tilman, D., Rockström, J., Willett, W., 2018. Options for keeping the food system within environmental limits. Nature. https://doi.org/10.1038/s41586-018-0594-0

Steffen, W., Richardson, K., Rockström, J., Cornell, S.E., Fetzer, I., Bennett, E.M., Biggs, R., Carpenter, S.R., de Vries, W., de Wit, C.A., Folke, C., Gerten, D., Heinke, J., Mace, G.M., Persson, L.M., Ramanathan, V., Reyers, B., Sörlin, S., 2015. Sustainability. Planetary boundaries: guiding human development on a changing planet. Science 347, 1259855. https://doi.org/10.1126/science.1259855

UNEP, 2019. Emissions gap report 2019. Nairobi.

United Nations, 2015. General Assembly, Transforming our world: the 2030 Agenda for Sustainable Development. https://doi.org/10.1080/714003707

Wang, X., Daigger, G., de Vries, W., Kroeze, C., Yang, M., Ren, N.-Q., Liu, J., Butler, D., 2019. Impact hotspots of reduced nutrient discharge shift across the globe with population and dietary changes. Nat. Commun. 10, 2627. https://doi.org/10.1038/s41467-019-10445-0 
201 Wenzel, H., Larsen, H.F., Clauson-Kaas, J., Høibye, L., Jacobsen, B.N., 2008. Weighing environmental advantages and disadvantages of advanced wastewater treatment of micro-pollutants using environmental life cycle assessment. Water Sci. Technol. 57, 27-32. https://doi.org/10.2166/wst.2008.819

205 WWAP, 2017. The United Nations World Water Development Report 2017. Wastewater: The Untapped 206 Resource. Paris. 